Impact of Type-2 Diabetes Mellitus on the Outcomes of Catheter Ablation of Atrial Fibrillation (European observational multicentre study)

Antonio Creta MD, Rui Providência MD PhD , Pedro Adragao MD PhD , Carlo de Asmundis MD PhD , Julian Chun MD , Gianbattista Chierchia MD PhD , Pascal Defaye MD , Boris Schmidt MD , Frédéric Anselme MD PhD, Malcolm Finlay MD PhD, Ross Jacob Hunter MD PhD , Nikolaos Papageorgiou MD PhD , Pier David Lambiase MD PhD , Richard John Schilling MD , Stephane Combes MD , Nicolas Combes MD , Jean-Paul Albenque MD , Paolo Pozzilli MD , Serge Boveda MD PhD

PII:

DOI: S0002-9149(19)31507-3

Reference: https://doi.org/10.1016/j.amjcard.2019.12.037 AJC 24365

To appear in: The American Journal of Cardiology

Received date:

23 October 2019

Revised date:

Accepted date:

17 December 2019

Please cite this article as: Antonio Creta MD, Rui Providência MD PhD , Pedro Adragao MD PhD , Carlo de Asmundis MD PhD , Julian Chun MD , Gianbattista Chierchia MD PhD , Pascal Defaye MD , Boris Schmidt MD , Frédéric Anselme MD PhD, Malcolm Finlay MD PhD, Ross Jacob Hunter MD PhD , Nikolaos Papageorgiou MD PhD , Pier David Lambiase MD PhD , Richard John Schilling MD , Stephane Combes MD, Nicolas Combes MD , Jean-Paul Albenque MD , Paolo Pozzilli MD , Serge Boveda MD PhD, Impact of Type-2 Diabetes Mellitus on the Outcomes of Catheter Ablation of Atrial Fibrillation (European observational multicentre study), The American Journal of Cardiology (2019), doi: https://doi.org/10.1016/j.amjcard.2019.12.037

This is a PDF file of an article that has undergone enhancements after acceptance, such as the addition of a cover page and metadata, and formatting for readability, but it is not yet the definitive version of record. This version will undergo additional copyediting, typesetting and review before it is published in its final form, but we are providing this version to give early visibility of the article. Please note that, during the production process, errors may be discovered which could affect the content, and all legal disclaimers that apply to the journal pertain.

(C) 2019 Elsevier Inc. All rights reserved. 


\section{Impact of Type-2 Diabetes Mellitus on the Outcomes of Catheter Ablation of Atrial Fibrillation (European observational multicentre study)}

Antonio Creta $\mathrm{MD}^{1,2}$, Rui Providência $\mathrm{MD} \mathrm{PhD}^{2,3,4}$, Pedro Adragao MD $\mathrm{PhD}^{5}$, Carlo de Asmundis $\mathrm{MD} \mathrm{PhD}^{6}$, Julian Chun $\mathrm{MD}^{7}$, Gianbattista Chierchia MD $\mathrm{PhD}^{6}$, Pascal Defaye $\mathrm{MD}^{8}$, Boris Schmidt $\mathrm{MD}^{7}$, Frédéric Anselme MD $\mathrm{PhD}^{9}$, Malcolm Finlay MD $\mathrm{PhD}^{2}$, Ross Jacob Hunter MD $\mathrm{PhD}^{2}$, Nikolaos Papageorgiou $\mathrm{MD} \mathrm{PhD}^{2}$, Pier David Lambiase MD $\mathrm{PhD}^{2}$, Richard John Schilling MD², Stephane Combes $\mathrm{MD}^{3}$, Nicolas Combes MD ${ }^{3}$, Jean-Paul Albenque $\mathrm{MD}^{3}$, Paolo Pozzilli MD ${ }^{1}$, Serge Boveda MD $\mathrm{PhD}^{3}$

1 Campus Bio-Medico University of Rome, Rome, Italy; ${ }^{2}$ Barts Heart Centre, St. Bartholomew's Hospital, London, United Kingdom; ${ }^{3}$ Clinic Pasteur of Toulouse, Toulouse, France; ${ }^{4}$ Institute of Health Informatics Research, University College of London, London, UK; ${ }^{5}$ Cardiology Department, Hospital de Santa Cruz, Lisbon, Portugal; ${ }^{6}$ Heart Rhythm Management Centre, Universiteit Ziekenhuis Brussel, Postgraduate program in Cardiac Electrophysiology and Pacing, Vrije Universiteit Brussel, Laarbeeklaan 101, 1090 Brussels, Belgium; ${ }^{7}$ Cardioangiologisches Centrum Bethanien, Medizinische Klinik III, Markus Krankenhaus, Wilhelm-Epstein-Street 4, D-60431 Frankfurt am Main, Germany; ${ }^{8} \mathrm{CHU}$ Michallon, Grenoble, France; Grenoble; ${ }^{9}$ University Hospital, Rouen, France.

Running title: diabetes mellitus and atrial fibrillation

Manuscript word count: 2236 words

\section{Corresponding author:}

Antonio Creta

Campus Bio-Medico University of Rome \& Barts Heart Centre

St. Bartholomew's Hospital

West Smithfield

London EC1A 7BE

Tel: +442037658646

Email: creta.antonio@gmail.com 


\section{Authors Contributions}

Antonio Creta: conceptualisation, methodology, validation, formal analysis, investigation, writing- original draft preparation. Rui Providência: methodology, validation, formal analysis, investigation, writing- review and editing. Pedro Adragao, Carlo de Asmundis, Julian Chun, Gianbattista Chierchia, Pascal Defaye, Boris Schmidt, Frédéric Anselme, Stephane Combes, Nicolas Combes, Jean-Paul Albenque: investigation. Malcolm Finlay, Ross Jacob Hunter, Nikolaos Papageorgiou, Pier David Lambiase, Richard John Schilling: investigation, writing- review and editing. Paolo Pozzilli: methodology, writingreview and editing. Serge Boveda: methodology, investigation, writing- review and editing, project administration. 


\begin{abstract}
Type-2 diabetes mellitus (DM) is associated with an increased risk of atrial fibrillation (AF). It is unclear whether DM is a risk factor for arrhythmia recurrence following catheter ablation of AF. We performed a non-randomised, observational study in 7 high-volume European centres. A total of 2504 patients undergoing catheter ablation of AF were included, and procedural outcomes were compared among patients with or without DM. Patients with DM (234) accounted for $9.3 \%$ of the sample, and were significantly older, had a higher BMI and suffered more frequently from persistent AF. Arrhythmia relapses at 12 months after AF ablation occurred more frequently in the DM group (32.0\% vs. $25.3 \%, \mathrm{p}=0.031)$. After adjusting for type of AF (i.e., paroxysmal vs. persistent), during a median follow-up of $17 \pm 16$ months, atrial arrhythmia free-survival was lower in the diabetics with persistent AF (logrank $\mathrm{p}=0.003)$, and comparable for paroxysmal $\mathrm{AF}$ (log-rank $\mathrm{p}=0.554)$. These results were confirmed in a propensity-matched analysis, and DM was also an independent predictor of $\mathrm{AF}$ recurrence on the multivariate analysis $\left(\mathrm{HR} 1.39 ; \mathrm{CI}_{95 \%} 1.07-1.88 ; \mathrm{p}=0.016\right)$. There was no significant difference in the rate of peri-procedural complications among DM and non-DM patients $(3.8 \%$ vs. $6.3 \%, \mathrm{p}=0.128)$. Efficacy and safety of cryoballoon ablation were comparable to radiofrequency ablation in both DM and no-DM groups. In conclusion, catheter ablation of AF appears to be safe in patients with DM. However, DM is associated with higher rate of atrial arrhythmia relapse, particularly for patients with persistent AF.
\end{abstract}

Key words: diabetes mellitus; atrial fibrillation; catheter ablation; rhythm control; cryoballoon. 


\section{Introduction}

Type-2 diabetes mellitus (DM) is associated with an increased risk of atrial fibrillation (AF) [1]. The physio-pathological connection between DM and AF is complex and multifactorial, including autonomic dysfunction, as well as atrial electrical, electromechanical, and structural remodelling [2]. Furthermore, DM increases the risk of thromboembolic complications of $\mathrm{AF}$, and diabetic patients with $\mathrm{AF}$ have greater risks for all-cause mortality, cardiovascular death, and heart failure [3-5]. Catheter ablation is a wellestablished and effective treatment for patients with symptomatic AF [6], however data regarding efficacy and safety in the DM population are mainly restricted to small size and single centre reports, with conflicting results [7] and limited use of the cryoballoon technique. We aim to further investigate implication of DM on the outcomes of catheter ablation of AF.

\section{Methods}

Non-randomised, observational study in 7 European centres. We included all patients aged over 18 undergoing a left atrial ablation procedure during a 24 months' time interval, with AF refractory to at least one class I or class III antiarrhythmic drug. All patients provided written informed consent prior to the procedure. We assessed DM as a potential independent predictor of AF/atrial tachycardia relapse. The study complied with the Declaration of Helsinki and the research protocol was approved by the local ethics committees. Demographics, admission day anthropometric data, and comorbidities were collected. Data from the referral transthoracic echocardiogram was analysed and a multislice computed tomography scan imaging of the left atrium was systematically collected preprocedure. Procedures were performed under sedation or general anaesthesia, according to each institution's protocol. Venous access was obtained via the femoral vein, with use of vascular ultrasound at operator's discretion. In the absence of patent foramen ovale, a single or dual transseptal puncture was performed under fluoroscopic guidance. Transesophageal 
echocardiography was used based on operator preference. Patients received intravenous heparin to maintain an activated clotting time of 300-350 seconds. Details of the AF ablation technique and peri-procedural management at our institutions have been published previously [8-10]. Basically, pulmonary vein isolation was the main procedural endpoint, and was performed as a first step in all procedures. If the patient was in AF at the start of the procedure and the arrhythmia organized into an atrial tachycardia this was mapped and ablated. In patients undergoing cryoballoon ablation, if the patient remained in AF after isolation of all four pulmonary veins, direct-current cardioversion to sinus rhythm was performed and no further ablation undertaken. In patients undergoing radiofrequency ablation of persistent $\mathrm{AF}$ and not cardioverting to sinus rhythm or not organizing to atrial tachycardia during ablation we mapped and ablated areas of complex fractionated atrial electrograms in both atria and the coronary sinus and subsequently DC cardioverted the patient if AF persisted. Patients were evaluated at 3, 6, and 12 months after the procedure. Information collected during follow-up included a 12-lead electrocardiogram (ECG) and 24-hour ECG Holter monitoring at each visit. Additional patient visits and further testing were allowed in case of symptoms. After the first year, follow-up was performed on an annual basis. Antiarrhythmic drugs were prescribed at discharge only for specific indications (i.e., relapse during the admission, need for cardioversion, longstanding persistent AF, etc.) and at the operator's discretion. In those instances, antiarrhythmic drugs were stopped after the first 3 months in the absence of recurrence. The first 3 months post-procedure were considered blanking period. Recurrence was defined as any symptomatic or asymptomatic atrial arrhythmia lasting >30 seconds following the 3 months blanking period. Patients with relapse during the blanking period with no response to pharmacologic or electrical cardioversion were also classified as having a relapse. 
The main efficacy endpoint was freedom from atrial arrhythmias following a blanking period of three months. AF or atrial tachycardia relapse during the initial 3-month blanking period was also documented. With regard to safety, the following complications were systematically recorded: vascular complications (if requiring intervention or prolongation of admission), thromboembolism (transient ischemic attack, stroke and/or systemic embolism during or in the first month after the procedure), phrenic nerve palsy, pericardial effusion (if causing haemodynamic instability and/or requiring pericardiocentesis or prolonged monitoring), oesophageal fistula, and procedure-related death. Other complications were reported at the discretion of the operator.

The chi-square test was used for categorical and t-student test for comparison of means was used for comparison of continuous variables. Levene's test was used to check the homogeneity of variance; equivalent non-parametric tests were used when KolmogorovSmirnov was in favour of the absence of normal distribution. Results with $P<0.05$ were regarded as significant.

Kaplan-Meier curves were traced for illustrating freedom from AF or atrial tachycardia among patients with or without $\mathrm{DM}$, and the log rank $\mathrm{P}$ test was used for assessing existing differences. Independent predictors of sinus rhythm maintenance after a single ablation procedure were assessed through Cox regression (Method: Forward Likelihood Ratio, Probability for Stepwise 0.05). A propensity score matching was performed to adjust for differences in baseline clinical characteristics, details are reported in the Supplementary materials. PASW Statistics version 18.0 was used for descriptive and inferential statistical analysis.

\section{Results}

A total of 2504 patients (mean age $61.1 \pm 10.2,29.4 \%$ female) underwent catheter ablation of AF. As much as 234 patients (9.3\%) suffered from DM. Most patients had 
paroxysmal $\mathrm{AF}(57.5 \%)$ at baseline, and mean AF duration was 5.0 \pm 5.4 years. The cryoballoon technique was adopted in $29.4 \%$ of the patients. The baseline population characteristics before and after propensity matching are reported in Tables 1 and S-1.

Pulmonary vein isolation was achieved at the end of the procedure in almost all the patients (99.0\%), with no significant differences between the two groups. Use of the cryoballoon was comparable among patients with or without DM. Rate of relapse during blanking was significantly more frequent in subjects with DM $(24.3 \%$ vs. $32.8 \%, \mathrm{p}=0.012)$. Similarly, relapses at 12 months occurred more frequently in the DM group (25.3 vs. $32.0 \%$, $\mathrm{p}=0.031$ ) (Table 2). After adjusting for type of AF (i.e., paroxysmal vs. persistent), during a median follow-up of $17 \pm 16$ months, atrial arrhythmia free-survival was lower in the diabetics vs. non-diabetics after ablation of persistent AF ( $\log$-rank $\mathrm{p}=0.003)$, and comparable after ablation of paroxysmal AF (log-rank $\mathrm{p}=0.554$ ). These findings were confirmed after comparing the DM patients vs. a propensity-matched group of non-diabetics (log-rank $\mathrm{p}=0.038$ for persistent AF). These results are shown in Figures 1 and $\mathrm{S}-1$.

Assessment of independent predictors of AF or arrhythmia relapse is illustrated in Table 3. On multivariate Cox regression, DM, BMI, AF duration and LA volume were independent predictors of relapse.

The rate of peri-procedural complications was similar among DM and non-DM patients $(3.8 \%$ vs. $6.4 \%, \mathrm{p}=0.128)$ (Table 2$)$. The incidence of cardiac tamponade, other bleeds, major vascular complications, phrenic nerve palsy, and stroke, transient ischemic attack or systemic embolism was very low and comparable.

Efficacy and safety of cryoballoon ablation were comparable to radiofrequency ablation in both DM and no-DM groups $(\log -$ rank $\mathrm{p}=0.437$ for persistent $\mathrm{AF}$ and $\mathrm{p}=0.531$ for paroxysmal AF). 


\section{Discussion}

The main finding of this multicentre study is that DM is associated with a higher incidence of atrial arrhythmia relapses at 12 months in patients undergoing catheter ablation of AF. On the Kaplan-Meier analysis, after adjusting for type of AF (i.e., paroxysmal vs. persistent), arrhythmia-free survival at a median follow-up of $17 \pm 16$ months was lower in diabetic patients with persistent AF compared to those with no DM; however, relapse rates were similar in DM vs. non-DM subjects undergoing ablation for paroxysmal AF. In our series, patients with DM have a higher prevalence of comorbidities such as hypertension, obstructive sleep apnoea, vascular disease and congestive heart failure, and more commonly suffer from non-paroxysmal forms of AF. However, on a multivariate analysis, after adjusting for confounding factors, DM remains an independent predictor of atrial arrhythmia relapses (HR1.39; $\left.\mathrm{CI}_{95 \%} 1.07-1.88 ; \mathrm{p}=0.016\right)$. The higher rate of post-ablation relapses in the DM population was also confirmed in a propensity-matched analysis. Finally, catheter ablation of AF appears to be safe in DM patients, with no significant difference in the complication rate compared to the non-diabetics. Notably, despite DM being a risk factor for thromboembolism in the AF population, we have found no differences in the number of periprocedure thromboembolic events between diabetics and non-diabetics. Efficacy and safety of the cryoballoon ablation was comparable to radiofrequency ablation in both DM and noDM group.

Our findings are clinically relevant, considering the high prevalence of DM and its strong association with AF. Subjects with DM have not only an increased risk of developing $\mathrm{AF}$, but are also more prone to AF-related complications such as thromboembolism and heart failure. For these reasons, DM patients might warrant the greatest benefit from an effective treatment of this arrhythmia, with the potential aim not only to improve quality of life, but also prevent its relevant clinical sequalae. The present study confirms that AF ablation is 
effective and safe in the DM population, despite this traditionally representing a higher risk sub-group with more frequent comorbidities. In fact, among DM patients, as much as $80.2 \%$ of those with paroxysmal AF and 57.6\% with persistent AF were free from atrial arrhythmia at the 12 months' follow-up. However, an important finding of our analysis is that DM is associated with higher long-term relapse rate after catheter ablation of persistent AF, while outcomes for paroxysmal AF are similar among diabetics and non-diabetics. DM is known to cause significant myocardial remodelling (i.e., diabetic cardiomyopathy) and can promote AF through several physio-pathological mechanisms $[2,5]$. It is conceivable that in diabetic patients, compared to the non-diabetic, persistent forms of AF are associated with a more severe degree of atrial myopathy and a more complex and multifactorial substrate, resulting in a lower long-term efficacy of catheter ablation. Indeed, DM has been independently associated with left atrial enlargement, regardless of concomitant hypertension and diastolic dysfunction [11]. Our finding could have relevant clinical implications, as an early ablative strategy might be particularly valuable in subjects with $\mathrm{DM}$, in order to prevent the progression from paroxysmal to persistent forms of $\mathrm{AF}$, as the latter appear to be more aggressive and difficult to treat.

The impact of DM on the outcomes of AF ablation has been previously evaluated by other authors, with conflicting results [7]. In the absence of randomised trials, to the best of our knowledge, the largest available controlled study included 339 DM patients from the German Ablation Registry [12]; in this series, after a median follow-up of 460 days, no differences were found between subjects with or without DM in terms of arrhythmia-free survival. However, these results included diabetic patients with both paroxysmal and persistent AF, and as such no separate outcomes were provided for subjects with different forms of AF; in addition, patients with persistent AF were underrepresented, and results were based on telephone follow-up only. A systematic review and metanalysis by Anselmino et al 
[13] showed similar outcomes of AF ablation in DM patients compared to the general population, although with relatively frequent need of redo procedure in the diabetics. However, data from a metanalysis including 886 individuals should be interpreted very carefully, especially in the context of relevant methodological bias such as the absence of a direct comparison with a control group.

Another relevant finding is that cryoballoon ablation appears to be effective and safe in DM patients, showing comparable results with the radiofrequency technique. These findings are of interest, as the diabetic population was underrepresented in most of the studies evaluating cryoballoon AF ablation; as such, the cornerstone FIRE and ICE trial included only 22 and 37 diabetic patients in the radiofrequency and cryoballoon group, respectively [14].

Finally, the results of the present study might suggest a potential benefit of an adequate treatment of DM to counteract its deleterious effect on the long-term outcomes of AF catheter ablation. The ARREST-AF study demonstrated that an aggressive risk factor management, including better glycaemic control, significantly improves arrhythmia-free survival after catheter ablation of AF [15]. However, although promising, these data should be confirmed in a prospective randomised fashion.

Several limitations should be acknowledged. First, no data regarding glycaemic control (e.g. HbA1c), DM duration and therapy were available. In addition, this was a multicentre study including experienced large volume centres, and might not represent the type of ablation activity performed in other centres with lower caseloads. Finally, systematic monitoring using an implantable loop recorder might have documented higher rate of asymptomatic recurrence. 
In conclusion, catheter ablation of $\mathrm{AF}$ appears to be safe in patients with DM. However, DM is associated with higher rate of atrial arrhythmia relapse after catheter ablation, particularly for patients with persistent AF.

Disclosures and Conflicts of Interest - AC has received educational grants from Boston Scientific and Abbott; JPL has received consultant fees from Abbott, and Biosense Webster; FA has received compensatory fees from Boston Scientific, Medtronic, and LivaNova; SB has received consulting fees from Medtronic, Boston Scientific, and Sorin Group; CdA receive compensation for teaching purposes and proctoring from AF solutions, Medtronic, Abbott, Biotronik, Atricure and research grants on behalf of the centre from Biotronik, Medtronic, Abbott, Livanova, Boston Scientific, and Biosense Webster; GBC receive compensation for teaching purposes and proctoring from AF solutions, Medtronic, and Biotronik; RJS has had research agreements and speaker fees from Abbott, Medtronic, Boston Scientific, and Biosense Webster; PDL has received educational grants from Medtronic and Boston Scientific; MF has received speaker fees from Biotronik and Medtronic, and owns stocks of Epicardio ltd. All other authors have reported that they have no relationships relevant to the contents of this paper to disclose. 


\section{References}

[1] Huxley RR, Filion KB, Konety S, Alonso A. Meta-analysis of cohort and case- control studies of type 2 diabetes mellitus and risk of atrial fibrillation. Am J Cardiol 2011;108:5662.

[2] Goudis CA, Korantzopoulos P, Ntalas IV, Kallergis EM, Liu T, Ketikoglou DG. Diabetes mellitus and atrial fibrillation: Pathophysiological mechanisms and potential upstream therapies. Int J Cardiol 2015;184:617-622.

[3] Gorenek B, Boriani G, Dan GA, Fauchier L, Fenelon G, Huang H, Kudaiberdieva G, Lip GYH, Mahajan R, Potpara T, Ramirez JD, Vos MA, Marin F. European Heart Rhythm Association (EHRA) position paper on arrhythmia management and device therapies in endocrine disorders, endorsed by Asia Pacific Heart Rhythm Society (APHRS) and Latin American Heart Rhythm Society (LAHRS). Europace 2018;20:895-896.

[4] Natale A, Reddy VY, Monir G, Wilber DJ, Lindsay BD, McElderry HT, Kantipudi C, Mansour MC, Melby DP, Packer DL, Nakagawa H, Zhang $\quad$ B, Stagg RB, Boo LM, Marchlinski FE. Paroxysmal AF catheter ablation with a contact force sensing catheter: results of the prospective, multicenter SMART-AF trial. J Am Coll Cardiol 2014;64:647-656. [5] Saunders J, Mathewkutty S, Drazner MH, McGuire DK. Cardiomyopathy in type 2 diabetes: update on pathophysiological mechanisms. Herz 2008;33:184-190.

[6] Verma A, Jiang CY, Betts TR, Chen J, Deisenhofer I, Mantovan R, Macle L, Morillo CA, Haverkamp W, Weerasooriya R, Albenque JP, Nardi S, Menardi E, Novak P, Sanders P; STAR AF II Investigators. Approaches to catheter ablation for persistent atrial fibrillation. N Engl J Med 2015;372:1812-1822.

[7] Wang A, Green JB, Halperin JL, Piccini JP. Atrial Fibrillation and Diabetes Mellitus. J Am Coll Cardiol 2019;74:1107-1115. 
[8] Squara F, Zhao A, Marijon E, Latcu DG, Providencia R, Di Giovanni G, Jauvert G, Jourda F, Chierchia GB, De Asmundis C, Ciconte G, Alonso C, Grimard C, Boveda S, Cauchemez B, Saoudi N, Brugada P, Albenque JP, Thomas O. Comparison between radiofrequency with contact force-sensing and second-generation cryoballoon for paroxysmal atrial fibrillation catheter ablation: a multicentre European evaluation. Europace 2015;17:718-724.

[9] Sousa PA, Providência R, Albenque JP, Khoueiry Z, Combes N, Combes S, Boveda S. Impact of Free Thyroxine on the Outcomes of Left Atrial Ablation Procedures. Am J Cardiol 2015;116:1863-1868.

[10] Providência R, Marijon E, Albenque JP, Combes S, Combes N, Jourda F, Hireche H, Morais J, Boveda S. Rivaroxaban and Dabigatran in patients undergoing catheter ablation of atrial fibrillation. Europace 2014;16:1137-1144.

[11] K.K. Kadappu, A. Boyd, S. Eshoo, B. Haluska, A.E. Yeo, T.H. Marwick, L. Thomas, Changes in left atrial volume in diabetes mellitus: more than diastolic dysfunction? Eur Heart J Cardiovasc Imaging 2012;13;1016-1023.

[12] Bogossian H, Frommeyer G, Brachmann J, Lewalter T, Hoffmann E, Kuck KH, Andresen D, Willems S, Spitzer SG, Deneke T, Thomas D, Hochadel M, Senges J, Eckardt L, Lemke B. Catheter ablation of atrial fibrillation and atrial flutter in patients with diabetes mellitus: Who benefits and who does not? Data from the German ablation registry. Int J Cardiol 2016;214:25-30.

[13] Anselmino M, Matta M, D'ascenzo F, Pappone C, Santinelli V, Bunch TJ, Neumann T, Schilling RJ, Hunter RJ, Noelker G, Fiala M, Frontera A, Thomas G, Katritsis D, Jais P, Weerasooriya R, Kalman JM, Gaita F. Catheter ablation of atrial fibrillation in patients with diabetes mellitus: a systematic review and meta-analysis. Europace 2015;17:15181525. 
[14] Kuck KH, Brugada J, Fürnkranz A, Metzner A, Ouyang F, Chun KR, Elvan A, Arentz T, Bestehorn K, Pocock SJ, Albenque JP, Tondo C; FIRE AND ICE Investigators. Cryoballoon or Radiofrequency Ablation for Paroxysmal Atrial Fibrillation. N Engl J Med 2016;374:2235-2245.

[15] Pathak RK, Middeldorp ME, Lau DH, Mehta AB, Mahajan R, Twomey D, Alasady M, Hanley L, Antic NA, McEvoy RD, Kalman JM, Abhayaratna WP, Sanders P. Aggressive risk factor reduction study for atrial fibrillation and implications for the outcome of ablation: the ARREST-AF cohort study. J Am Coll Cardiol 2014;64:2222-2231. 


\section{Legends to figures}
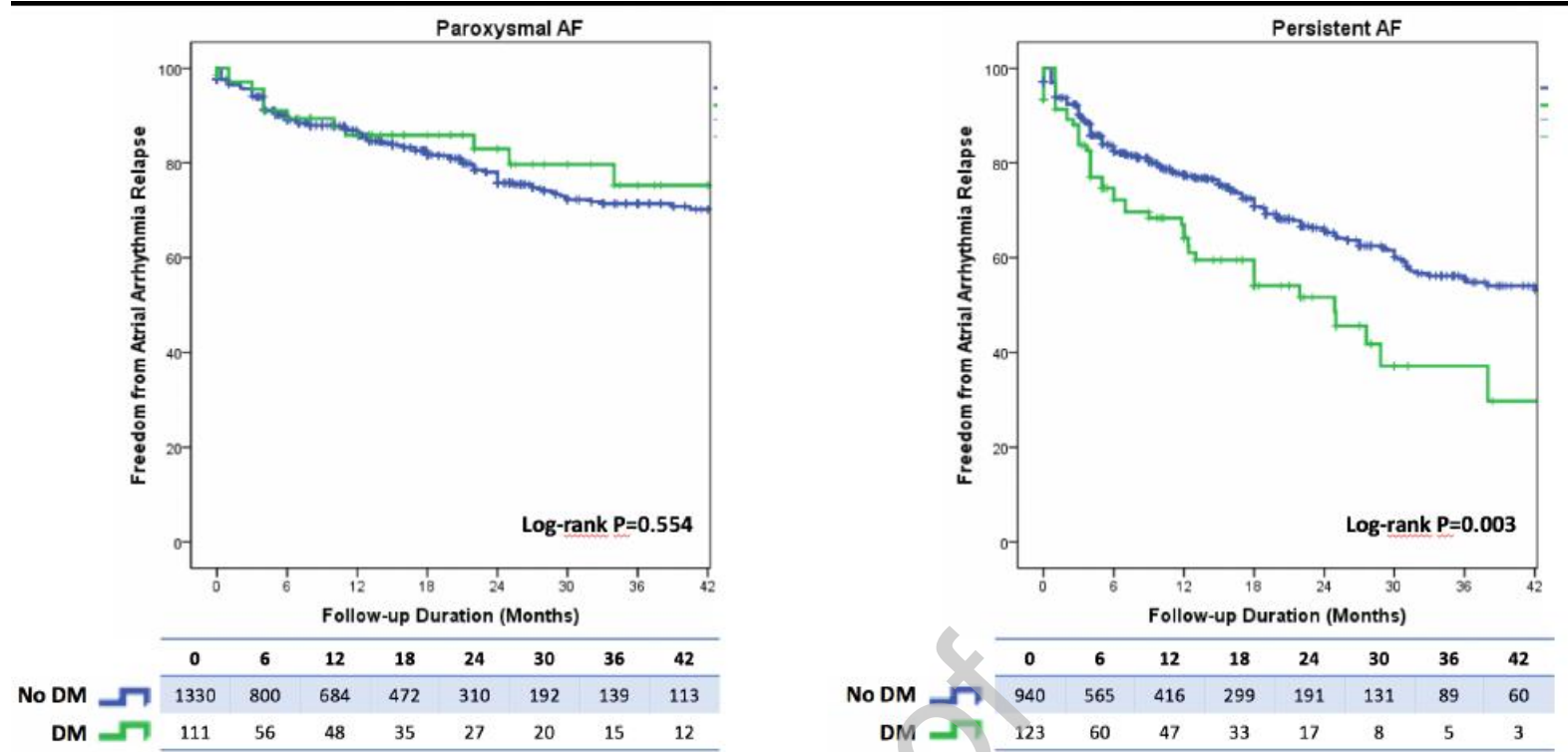

Figure 1. Kaplan-Meier of atrial arrhythmia-free survival

Tables

Table 1. Baseline characteristics of the study population

Table 2. Efficacy and Safety Endpoints

Table 3. Predictors of Post-blanking atrial arrhythmia relapse after an ablation procedure 
Table 1 - Baseline characteristics of the study population

\begin{tabular}{|c|c|c|c|c|}
\hline \multirow[b]{2}{*}{ Variable } & \multirow{2}{*}{$\begin{array}{l}\text { Total } \\
\text { sample } \\
(n=2504)\end{array}$} & \multicolumn{2}{|c|}{ Diabetes mellitus } & \multirow{2}{*}{$\begin{array}{ll} & \text { Over } \\
\text { all } & \\
& P\end{array}$} \\
\hline & & $\begin{array}{c}\text { NO } \\
(n=2270)\end{array}$ & $\begin{array}{c}\text { YES } \\
(n=234)\end{array}$ & \\
\hline Age (years) & $61.1 \pm 10.2$ & $60.8 \pm 10.4$ & $63.9 \pm 7.5$ & $1^{<0.00}$ \\
\hline Women & $29.4 \%(736)$ & $\begin{array}{l}29.3 \% \\
(665)\end{array}$ & $30.3 \%(71)$ & 0.738 \\
\hline $\begin{array}{l}\text { AF duration } \\
\text { (years) }\end{array}$ & $5.0 \pm 5.4$ & $5.0 \pm 5.4$ & $4.6 \pm 4.2$ & 0.405 \\
\hline $\begin{array}{l}\text { Paroxysmal } \\
\text { AF }\end{array}$ & $\begin{array}{l}57.5 \% \\
(1441)\end{array}$ & $\begin{array}{l}58.6 \% \\
(1330)\end{array}$ & $\begin{array}{l}47.4 \% \\
(111)\end{array}$ & \multirow{2}{*}{$1<0.00$} \\
\hline Persistent AF & $\begin{array}{l}42.5 \% \\
(1063)\end{array}$ & $\begin{array}{l}41.4 \% \\
(940)\end{array}$ & $\begin{array}{l}52.6 \% \\
(123)\end{array}$ & \\
\hline $\begin{array}{l}\text { Mean N of } \\
\text { Procedures }\end{array}$ & $1.2 \pm 0.5$ & $1.2 \pm 0.5$ & $1.2 \pm 0.5$ & 0.729 \\
\hline $\begin{array}{l}\mathrm{CHA}_{2} \mathrm{DS}_{2^{-}} \\
\mathrm{VASc}\end{array}$ & $1.6 \pm 1.4$ & $1.5 \pm 1$. & $3.0 \pm 1.2$ & $1^{<0.00}$ \\
\hline $\begin{array}{l}\text { Congestive } \\
\text { heart failure }\end{array}$ & $8.1 \%(202)$ & $\begin{array}{l}7.4 \% \\
(168)\end{array}$ & $14.5 \%(34)$ & $1^{<0.00}$ \\
\hline Hypertension & $\begin{array}{l}45.8 \% \\
(1,148)\end{array}$ & $43 \%(976)$ & $\begin{array}{l}73.5 \% \\
(172)\end{array}$ & $1^{<0.00}$ \\
\hline BMI $\left(\mathrm{Kg} / \mathbf{m}^{2}\right)$ & $28.4 \pm 13.3$ & $28.1 \pm 13.0$ & $31.6 \pm 15.5$ & $1^{<0.00}$ \\
\hline Stroke or TIA & $7.5 \%$ & ${ }^{7.4 \%}$ & $9.0 \%(21)$ & 0.371 \\
\hline $\begin{array}{l}\text { Vascular } \\
\text { disease }\end{array}$ & $8.5 \%(213)$ & ${ }^{(167)^{7.4 \%}}$ & $19.7 \%(46)$ & $1^{<0.00}$ \\
\hline $\begin{array}{l}\text { Obstructive } \\
\text { Sleep apnea }\end{array}$ & $7.0 \%(176)$ & $\begin{array}{l}6.4 \% \\
(145)^{-}\end{array}$ & $13.2 \%(31)$ & $1^{<0.00}$ \\
\hline $\begin{array}{c}\text { eGFR } \\
(\mathrm{ml} / \mathrm{min})\end{array}$ & $75.1 \pm 18.4$ & $75.5 \pm 18.0$ & $71.1 \pm 21.3$ & 0.009 \\
\hline $\begin{array}{l}\text { Indexed LA } \\
\text { volume }\left(\mathrm{mL} / \mathrm{m}^{2}\right)\end{array}$ & $48.6 \pm 18.6$ & $48.3 \pm 18.7$ & $51.2 \pm 17.4$ & 0.043 \\
\hline LVEF (\%) & $61.4 \pm 9$ & $61.9 \pm 8.6$ & $59.7 \pm 9.1$ & 0.002 \\
\hline $\begin{array}{l}\text { Cryoballoon } \\
\text { ablation }\end{array}$ & $29.4 \%(736)$ & $\begin{array}{l}29.4 \% \\
(668)\end{array}$ & $29.1 \%(68)$ & 0.906 \\
\hline $\begin{array}{c}\text { Use of } \\
\text { General Anaesthesia }\end{array}$ & $\begin{array}{l}67.6 \% \\
(1,692)\end{array}$ & $\begin{array}{l}67.7 \% \\
(1536)\end{array}$ & $\begin{array}{l}66.7 \% \\
(156)\end{array}$ & 0.746 \\
\hline $\begin{array}{l}\text { Procedure } \\
\text { Duration (min) }\end{array}$ & $136 \pm 58$ & $134 \pm 57$ & $141 \pm 59$ & 0.094 \\
\hline $\begin{array}{l}\text { Fluoroscopy } \\
\text { Duration (min) }\end{array}$ & $23 \pm 13$ & $23 \pm 13$ & $23 \pm 13$ & 0.406 \\
\hline $\begin{array}{l}\text { Class I or III } \\
\text { AADs on discharge }\end{array}$ & $21.6 \%(542)$ & $\begin{array}{l}25.5 \% \\
(483)\end{array}$ & $31.2 \%(59)$ & 0.089 \\
\hline $\begin{array}{l}\text { CFAE } \\
\text { ablation }\end{array}$ & $14.2 \%(356)$ & $\begin{array}{l}13.8 \% \\
(313)\end{array}$ & $18.4 \%(43)$ & 0.056 \\
\hline LA lines & $23 \%(576)$ & $\begin{array}{l}22.4 \% \\
(508)\end{array}$ & $29.1 \%(68)$ & 0.201 \\
\hline CTI & $21.8 \%(546)$ & $21.7 \%$ & $23.1 \%(54)$ & 0.621 \\
\hline
\end{tabular}




\section{NYHA}

$1.1 \pm 0.4$

$1.1 \pm 0.4$

$1.2 \pm 0.5$

0.008

Legend: Values are given as mean $\pm \mathrm{SD}$ or number and $(\%)$. $\mathrm{AF}$ - atrial fibrillation; $\mathrm{CHA}_{2} \mathrm{DS}_{2}-\mathrm{VASc}-$ cardiac failure or dysfunction, hypertension, age $\geq 75$ years [doubled], diabetes, stroke [doubled] - vascular disease, age 65-74 years, sex category [female]; TIA - transitory ischemic attack; LA - left atrium; LVEF - left ventricular ejection fraction; AAD anti-arrhythmic drugs; SD - standard deviation.

Table 2 - Efficacy and Safety Endpoints

\begin{tabular}{|c|c|c|c|c|c|c|}
\hline & \multirow[b]{2}{*}{ Variable } & \multirow{2}{*}{$\begin{array}{c}\text { Total } \\
\text { sample } \\
)^{(n=2504}\end{array}$} & \multicolumn{2}{|c|}{ Diabetes mellitus } & \multirow[b]{2}{*}{ erall } & \multirow[b]{2}{*}{$\begin{array}{l}\text { Ov } \\
\mathbf{P}\end{array}$} \\
\hline & & & $\begin{array}{r}\text { NO } \\
(n=2270)\end{array}$ & 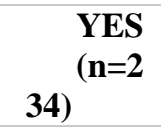 & & \\
\hline \multirow{3}{*}{ 选 } & $\begin{array}{l}\text { Pulmonary Vein } \\
\text { Isolation }\end{array}$ & $\begin{array}{l}99.0 \% \\
(2,479)\end{array}$ & $\begin{array}{l}99.0 \% \\
(2248)\end{array}$ & $\begin{array}{l}98.7 \% \\
(231)\end{array}$ & 47 & 0.6 \\
\hline & $\begin{array}{l}\text { Relapse during } \\
\text { blanking }\end{array}$ & $\begin{array}{l}20.2 \% \\
(506)\end{array}$ & $\begin{array}{l}24.3 \% \\
(446)\end{array}$ & $(60)^{32.8 \%}$ & 12 & 0.0 \\
\hline & $\begin{array}{l}\text { Relapse during } \\
\text { first } 12 \text { months }\end{array}$ & $\begin{array}{l}28.9 \% \\
(623)^{2}\end{array}$ & $25.3 \%$ & $\begin{array}{l}32.0 \% \\
(70)^{3}\end{array}$ & 31 & 0.0 \\
\hline \multirow{8}{*}{$\frac{D^{ \pm}}{\frac{\pi}{\sigma}}$} & $\begin{array}{l}\text { Peri-procedural } \\
\text { complications }\end{array}$ & $(152)^{6.1 \%}$ & (143) & (9) $3.8 \%$ & 28 & 0.1 \\
\hline & $\begin{array}{l}\text { Cardiac } \\
\text { tamponade }\end{array}$ & $0.7 \%(18)$ & $0.7 \%(15)$ & (3) $1.3 \%$ & 84 & 0.2 \\
\hline & TIA & $0.2 \%(4)$ & $0.2 \%(4)$ & (0) & 20 & 0.5 \\
\hline & Stroke & $0.2 \%(6)$ & $0.3 \%(6)$ & (0) & 31 & 0.4 \\
\hline & $\begin{array}{l}\text { Transient phren } \\
\text { nerve palsy }\end{array}$ & $1.5 \%(37)$ & $1.5 \%(35)$ & (2) $0.9 \%$ & 07 & 0.4 \\
\hline & $\begin{array}{l}\text { Major vascular } \\
\text { complications }\end{array}$ & $2.6 \%(65)$ & $2.7 \%(62)$ & (3) $1.3 \%$ & 84 & 0.1 \\
\hline & $\begin{array}{l}\text { Procedure-related } \\
\text { death* }\end{array}$ & $0.1 \%(1)$ & $0 \%(1)$ & (0) & 48 & 0.7 \\
\hline & $\begin{array}{l}\text { Other } \\
\text { complications }\end{array}$ & $0.8 \%(21)$ & $0.9 \%(20)$ & (1) $0.4 \%$ & 69 & 0.4 \\
\hline \multirow{7}{*}{ 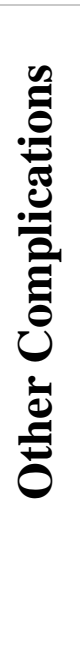 } & Esophageal fistula & $0.1 \%(2)$ & $0.1 \%(2)$ & (0) & 40 & 0.6 \\
\hline & Gastroparesis & $0.1 \%(2)$ & $0.1 \%(2)$ & $0 \%()$ & 50 & 0.6 \\
\hline & Esophageal ulcer & $0.1 \%(1)$ & $0 \%(1)$ & (0) & 48 & 0.7 \\
\hline & $\begin{array}{l}\text { Non-Access related } \\
\text { bleeds }\end{array}$ & $0.2 \%(6)$ & $0.2 \%(5)$ & (1) $0.4 \%$ & 37 & 0.5 \\
\hline & $\begin{array}{l}\text { Bradyarrhythmic } \\
\text { complications }\end{array}$ & $0.2 \%(5)$ & $0.2 \%(5)$ & (0) & 72 & 0.4 \\
\hline & Anaphylaxis & $0.1 \%(1)$ & $0 \%(1)$ & (0) & 48 & 0.7 \\
\hline & $\begin{array}{c}\text { Transient } \\
\text { myocardial stunning }\end{array}$ & $0.1 \%(1)$ & $0 \%(1)$ & (0) & 48 & 0.7 \\
\hline
\end{tabular}




\begin{tabular}{|cccccc|}
\hline PV stenosis & $0.1 \%(1)$ & $0 \%(1)$ & $0 \%$ & 0.7 & 48 \\
\hline Air embolism & $0.1 \%(1)$ & $0 \%(1)$ & $0 \%$ & $(0)$ & 48 \\
\hline $\begin{array}{c}\text { Acute pulmonary } \\
\text { edema }\end{array}$ & $0.1 \%(1)$ & $0 \%(1)$ & $0 \%$ & 0.7 \\
\hline
\end{tabular}

Legend: Values are given as number and $(\%)$, and incidence and $(95 \% \mathrm{CI})$. Legend: TIA - transient ischaemic attack; CI - confidence interval. * Death occurred as a result of diffuse lung bleed without identifiable source.

Table 3 - Predictors of Post-blanking atrial arrhythmia relapse after an ablation procedure

\begin{tabular}{|c|c|c|c|c|c|c|c|c|}
\hline \multirow{2}{*}{$\begin{array}{l}\text { Variabl } \\
\text { e }\end{array}$} & \multicolumn{4}{|c|}{$\begin{array}{l}\text { Univariate Cox } \\
\text { Regression }\end{array}$} & \multicolumn{4}{|c|}{$\begin{array}{l}\text { Multivariate Cox } \\
\text { Regression }\end{array}$} \\
\hline & $\mathbf{R}$ & $\% \mathrm{CI}^{9}$ & & $\mathbf{I}$ & $\mathbf{R}$ & H & $\% \mathrm{CI}^{95}$ & $\mathbf{P}$ \\
\hline $\begin{array}{l}\text { Age (per } \\
\text { year) }\end{array}$ & .01 & $00-1.01^{1}$ & .027 & ( & & & - & - \\
\hline Women & .10 & $96-1.28^{0}$ & .146 & C & & & - & - \\
\hline $\begin{array}{l}\text { AF duration } \\
\text { (per year) }\end{array}$ & .02 & $01-1.03$ & 0.001 & 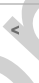 & .02 & 1 & $1.04^{1.01-}$ & $0.001<$ \\
\hline $\begin{array}{l}\text { Paroxysmal } \\
\text { AF }\end{array}$ & .54 & $47-0.61^{0}$ & 0.001 & 4 & .55 & 0 & $0.65^{0.46-}$ & $0.001<$ \\
\hline $\begin{array}{l}\text { Congestive } \\
\text { heart failure }\end{array}$ & .74 & $42-2.13^{1}$ & 0.001 & 4 & & - & - & - \\
\hline $\begin{array}{l}\text { Hypertensio } \\
\text { n }\end{array}$ & .18 & 04-1.34 & .013 & ( & & - & - & - \\
\hline $\begin{array}{l}\text { Diabetes } \\
\text { mellitus }\end{array}$ & .39 & $13-1.71^{1}$ & .002 & ( & .39 & 1 & $1.82^{1.07-}$ & $.016^{0}$ \\
\hline $\begin{array}{l}\text { Stroke or } \\
\text { TIA }\end{array}$ & 24 & $98-1.55^{0}$ & .071 & ( & & - & - & - \\
\hline $\begin{array}{l}\text { Vascular } \\
\text { disease }\end{array}$ & .27 & $03-1.58$ & .026 & ( & & - & - & - \\
\hline $\begin{array}{l}\text { Obstructive } \\
\text { Sleep Apnea }\end{array}$ & .34 & $06-1.68^{1}$ & .013 & ( & & - & - & - \\
\hline $\begin{array}{l}\mathrm{CHA}_{2} \mathrm{DS}_{2-} \\
\mathrm{VASc}\end{array}$ & .12 & $07-1.17^{1}$ & 0.001 & 4 & & - & - & - \\
\hline $\begin{array}{l}\mathrm{BMI} \\
\left.\mathrm{Kg} / \mathrm{m}^{2}\right)\end{array}$ & .01 & $00-1.01^{1}$ & .024 & ( & .03 & 1 & $1.05^{1.02-}$ & 0.001 \\
\hline $\begin{array}{l}\text { eGFR (per } \\
\mathrm{ml} / \mathrm{min} \text { ) }\end{array}$ & .99 & $99-1.00$ & .149 & ( & & - & - & - \\
\hline $\begin{array}{r}\text { Indexed LA } \\
\text { volume }\left(\text { per } \mathrm{mL} / \mathrm{m}^{2}\right)\end{array}$ & .01 & $01-1.02^{1}$ & 0.001 & 4 & .01 & 1 & $1.01^{1.00-}$ & $0.001<$ \\
\hline $\begin{array}{l}\text { LVEF (per } \\
\%)\end{array}$ & .99 & 98-0.99 & 0.001 & 4 & & - & - & - \\
\hline $\begin{array}{l}\text { Cryoballoon } \\
\text { ablation }\end{array}$ & .92 & $80-1.06^{0}$ & .274 & ( & & - & - & - \\
\hline NYHA & .57 & $36-1.83$ & 0.001 & ' & & - & - & - \\
\hline CTI & .97 & $83-1.13^{0}$ & .682 & ( & & - & - & - \\
\hline
\end{tabular}

Legend: HR - hazard ratio; CI - confidence interval; AF - atrial fibrillation; TIA - transitory ischemic attack; $\mathrm{CHA}_{2} \mathrm{DS}_{2}$-VASc - cardiac failure or dysfunction, hypertension, age $\geq 75$ years [doubled], diabetes, stroke [doubled] vascular disease, age 65-74 years, sex category [female]; BMI - body mass index; LA - left atrium; LVEF - left ventricular ejection fraction; AAD - anti-arrhythmic drugs. 